\title{
DoE/PC/94063--13
}

\section{Production and Screening of Carbon Products Precursors From Coal}

\author{
Quarterly Report \\ January 1 - March 31, 1998
}

Work Performed Under Contract No.: DE-AC22-95PC94063

For

U.S. Department of Energy

Office of Fossil Energy

Federal Energy Technology Center

P.O. Box 880

Morgantown, West Virginia 26507-0880

By

West Virginia University Research Corporation on behalf of West Virginia University

617 N. Spruce Street

Morgantown, West Virginia 26506

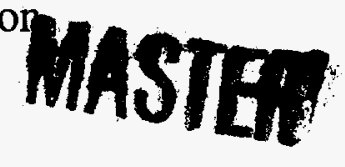




\section{Disclaimer}

This report was prepared as an account of work sponsored by an agency of the United States Government. Neither the United States Government nor any agency thereof, nor any of their employees, makes any warranty, express or implied, or assumes any legal liability or responsibility for the accuracy, completeness, or usefulness of any information, apparatus, product, or process disclosed, or represents that its use would not infringe privately owned rights. Reference herein to any specific commercial product, process, or service by trade name, trademark, manufacturer, or otherwise does not necessarily constitute or imply its endorsement, recommendation, or favoring by the United States Government or any agency thereof. The views and opinions of authors expressed herein do not necessarily state or reflect those of the United States Government or any agency thereof. 


\section{DISCLAIMER}

Portions of this document may be illegible electronic image products. Images are produced from the best available original document. 


\section{Table of Contents}

QUARTERLY TECHNICAL PROGRESS REPORT 3

1. Processing and Characterization of HTI Bottoms by NMP Extraction................3

Table 1. Properties of acid-washed coal liquid and centrifuged coal liquid...................3

Figure 1. Optical texture developed by the acid-washed HTI coal liquid ..................... 4

Table 2. Properties of acid-treated HTI coal-derived pitch as determined by Koppers. 5

Table 3. Viscosity of acid-treated HTI coal-derived pitch at selected temperatures......5 


\title{
QUARTERLY TECHNICAL PROGRESS REPORT NUMBER 13
}

\author{
January 1, 1998 to March 31, 1998
}

\section{Processing and Characterization of HTI Bottoms by NMP Extraction}

It was reported last quarter that attempts to reduce the ash content of the Hydrocarbon Technology, Inc. (HTI) bottoms material following N-methyl pyrrolidone (NMP) extraction and centrifugation produced a coal-derived pitch with an ash content of $0.7 \mathrm{wt} \%$. Additional processing by pressure filtration through a $0.2 \mu \mathrm{m}$ Teflon filter produced a coal-derived pitch with an ash content of $0.5 \mathrm{wt} \%$. The latter result indicates that the ash-forming constituents are sub-micron in dimensions.

Because the ash exhibited the color of an iron oxide, the assumption was made that the ash-forming matter is primarily iron based. Thus, a portion of the inorganics may be soluble in a dilute solution of $\mathrm{HCl}$ acid. To test this assumption, $200 \mathrm{~g}$ of the coal liquid were redissolved in $1.5 \mathrm{~L}$ of NMP. To this was added a solution comprised of 10 $\mathrm{mL}$ of concentrated $\mathrm{HCl}$ in $100 \mathrm{~mL}$ of deionized water. The mixture was stirred overnight at $60^{\circ} \mathrm{C}$. Afterward, the mixture was cooled to room temperature and $2 \mathrm{~L}$ of deionized water added to precipitate the coal liquid. The supernatant liquid was decanted and the precipitate washed an additional two times with deionized water. Finally, the precipitated coal material was vacuum dried overnight at $170^{\circ} \mathrm{C}$.

Table 1 compares some data of the properties of the acid-washed coal liquid with those from centrifugation alone. It is evident that the acid treatment was effective in reducing the quantity of ash significantly. In addition, because some of the lighter coal components were discarded with the supernatant liquid, the coke yield, real density, and softening point temperature all increased.

Table 1. Properties of acid-washed coal liquid and centrifuged coal liquid.

\begin{tabular}{|l|c|c|}
\cline { 2 - 3 } \multicolumn{1}{c|}{} & Acid Washed & Centrifugation \\
\hline Softening Point, ${ }^{\circ} \mathrm{C}$ & 127.1 & 101.8 \\
\hline Density, $\mathrm{g} / \mathrm{cm}^{3}$ & 1.203 & 1.187 \\
\hline Coke Yield, wt\% & 43.9 & 37.3 \\
\hline Ash Content, wt\% & 0.11 & 0.70 \\
\hline
\end{tabular}


Figure 1 is a photomicrograph of the coke structure developed by the acid-washed coal liquid. Note the degree of anisotropy does not seem to be adversely affected by the acid treatment.

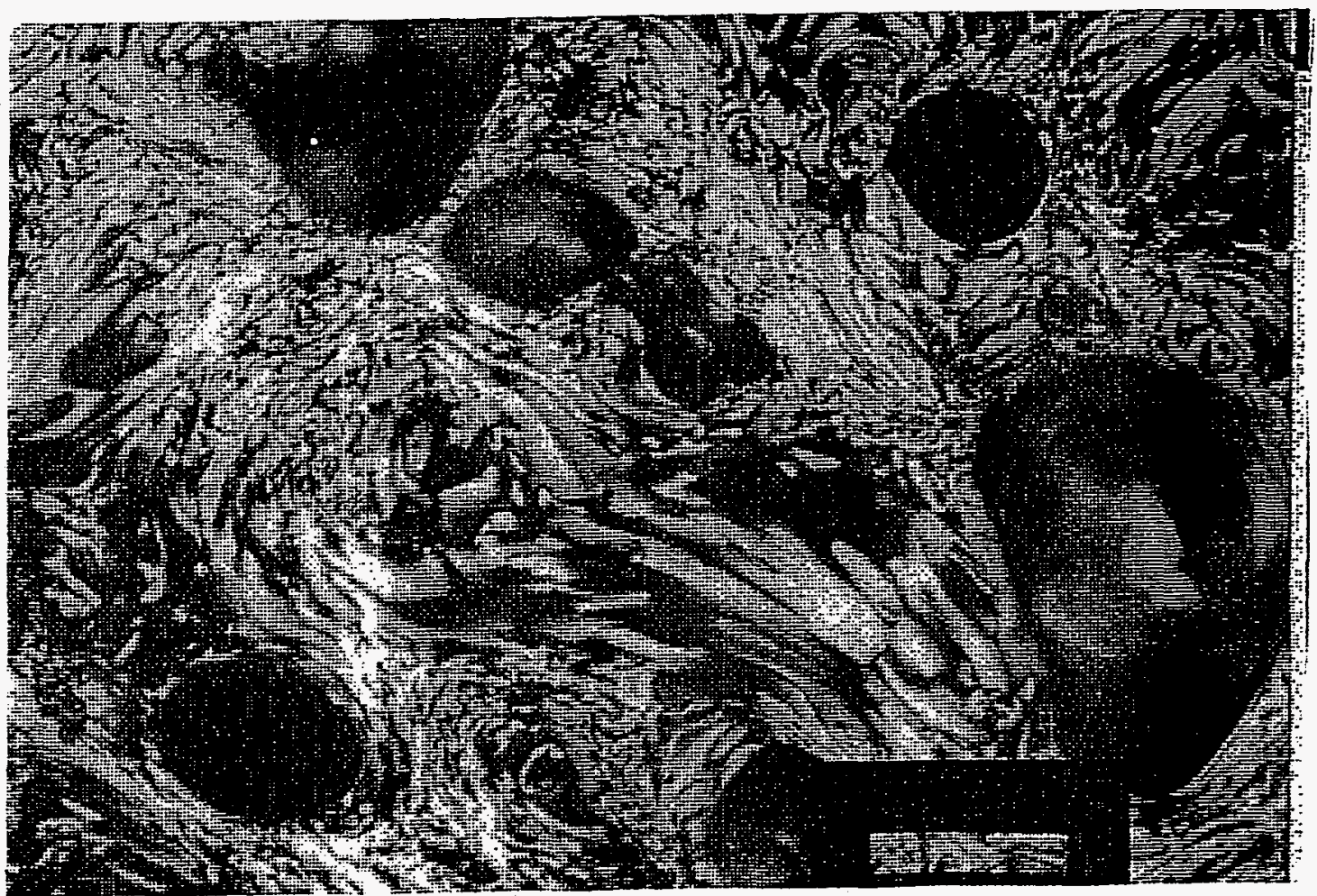

Figure 1. Optical texture developed by the acid-washed HTI coal liquid

The acid treatment was repeated in batches several times until about $4 \mathrm{~kg}$ of cleaned coal product was produced. About $1 \mathrm{~kg}$ of the coal-derived pitch was sent to Koppers for examination by their battery of tests. A portion of the pitch was carbonized into green coke and also sent to Koppers for petrographic analysis, the results to be reported when they become available. Table 2 shows the results of the tests of the $\mathrm{HCl}$ treated coal pitch. 
Table 2. Properties of acid-treated HTI coal-derived pitch as determined by Koppers.

\begin{tabular}{|l|c|}
\hline Softening Point, ${ }^{\circ} \mathrm{C}$ & 130.5 \\
\hline Quinoline Insolubles, wt\% & 0.3 \\
\hline Toluene Insolubles, wt\% & 21.4 \\
\hline Conradson Coking Value, wt\% & 40.6 \\
\hline Ash Content, wt\% & 0.15 \\
\hline Volatility, wt\% & 6.04 \\
\hline Specific Gravity & 1.189 \\
\hline C/H Atomic Ratio & 1.10 \\
\hline
\end{tabular}

The values determined by Koppers for the softening point temperature, coke residue, ash content, and specific gravity agree well with those determined by West Virginia University.

The viscosity of the pitch at different temperatures was also determined by Koppers, with the results presented in Table 3.

Table 3. Viscosity of acid-treated HTI coal-derived pitch at selected temperatures.

\begin{tabular}{|c|c|}
\hline Temperature, ${ }^{\circ} \mathrm{C}$ & Viscosity, centipoise \\
\hline 160 & 14,400 \\
\hline 180 & 3,385 \\
\hline 200 & 805 \\
\hline
\end{tabular}

About $0.4 \mathrm{~kg}$ of the acid-treated material was converted into green coke and samples prepared for examination by Alcoa. Results will be reported when they become available. 